\title{
5 -Hydroxymethylcytosine is an essential intermediate of active DNA demethylation processes in primary human monocytes
}

\author{
Maja Klug ${ }^{1,3+}$, Sandra Schmidhofer ${ }^{1 \dagger}$, Claudia Gebhard ${ }^{1}$, Reinhard Andreesen ${ }^{2}$ and Michael Rehli ${ }^{1 *}$
}

\begin{abstract}
Background: Cytosine methylation is a frequent epigenetic modification restricting the activity of gene regulatory elements. Whereas DNA methylation patterns are generally inherited during replication, both embryonic and somatic differentiation processes require the removal of cytosine methylation at specific gene loci to activate lineage-restricted elements. However, the exact mechanisms facilitating the erasure of DNA methylation remain unclear in many cases.

Results: We previously established human post-proliferative monocytes as a model to study active DNA demethylation. We now show, for several previously identified genomic sites, that the loss of DNA methylation during the differentiation of primary, post-proliferative human monocytes into dendritic cells is preceded by the local appearance of 5-hydroxymethylcytosine. Monocytes were found to express the methylcytosine dioxygenase Ten-Eleven Translocation (TET) 2, which is frequently mutated in myeloid malignancies. The siRNA-mediated knockdown of this enzyme in primary monocytes prevented active DNA demethylation, suggesting that TET2 is essential for the proper execution of this process in human monocytes.

Conclusions: The work described here provides definite evidence that TET2-mediated conversion of 5methylcytosine to 5-hydroxymethylcytosine initiates targeted, active DNA demethylation in a mature postmitotic myeloid cell type.
\end{abstract}

Keywords: Epigenetics, active DNA demethylation, differentiation

\section{Background}

DNA methylation is a frequent epigenetic modification that restricts the activity of regulatory elements, including cell type-specific gene promoters and enhancers. In mammals, methylated cytosines $(5 \mathrm{mC})$ mainly occur in the context of CpG dinucleotides and the targeted setting and erasure of the methylation mark is crucial for the silencing of repetitive and potentially harmful elements and for the proper execution of essential regulatory programs including embryonic development, X-chromosome inactivation, parental imprinting as well as cellular differentiation $[1,2]$. While the process of cytosine methylation, which is catalyzed by a group of DNA methyl-transferases (DNMTs) is

\footnotetext{
* Correspondence: michael.rehli@klinik.uni-regensburg.de

† Contributed equally

'Department of Internal Medicine III, University Hospital Regensburg, D-

93042 Regensburg, Germany

Full list of author information is available at the end of the article
}

well characterized, the exact mechanisms facilitating the erasure of DNA methylation in mammals remain less clear and the proposed existence of active enzymatic demethylation processes has been a matter of controversy over the last decades [3].

Recent pioneering work has identified the family of TenEleven-Translocation proteins (TET1-3) that catalyze the conversion of $5 \mathrm{mC}$ to 5 -hydroxy-methylcytosine $(5 \mathrm{hmC})$ in mammalian cells [4], and has prompted speculations that these enzymes are involved in DNA demethylation processes $[5,6]$. On the one hand, $5 \mathrm{hmC}$ could interfere with maintenance methylation and induce a passive demethylation process. On the other hand, TET enzymes may also initiate active demethylation processes through repair-associated mechanisms [7].

\section{Biomed Central}

(c) 2013 Klug et al.; licensee BioMed Central Ltd. This is an open access article distributed under the terms of the Creative Commons Attribution License (http://creativecommons.org/licenses/by/2.0), which permits unrestricted use, distribution, and reproduction in any medium, provided the original work is properly cited. 
Global DNA demethylation is observed during early embryonal development in particular in zygotes and primordial germ cells and $5 \mathrm{hmC}$ has been detected in both pathways $[8,9]$. The initial massive erasure of $5 \mathrm{mC}$ in primordial germ cells, however, appears to be a TET-independent, passive process that is likely controlled by the downregulation of UHRF1, which facilitates the recruitment of the maintenance DNA-methyltransferase DNMT1 to nascent hemimethylated DNA at the replication fork [10]. In the zygote, however, TET3 mediated conversion of $5 \mathrm{mC}$ to $5 \mathrm{hmC}$ is essential for the reprogramming of the zygotic paternal DNA after fertilization [11-13]. $5 \mathrm{hmC}$ is then gradually replaced by unmethylated cytosines during preimplantation development, suggesting that the erasure of $5 \mathrm{hmC}$ in zygotes is also a DNA replication-dependent passive process [12].

Another member of this family (TET2) directly affects myelopoiesis and diverse myeloid malignancies (including myelodysplastic syndromes, chronic myelomonocytic leukemia, myeloproliferative neoplasms, and acute myeloid leukemia) are frequently associated with mutations in this gene [14-16]. Targeted disruption or knockdown of TET2 results in reduced levels of $5 \mathrm{hmC}$ and affects self-renewal and differentiation of hematopoietic stem cells [17-20]. However, the exact mechanisms that contribute to disease pathology are currently unknown.

Here we provide direct evidence that the TET2-dependent conversion of $5 \mathrm{mC}$ to $5 \mathrm{hmC}$ is required for active DNA demethylation in primary human monocytes. Similar processes are likely to occur in other myeloid (progenitor) cells and the reduced ability to erase DNA methylation at critical regulatory sites in cases with TET2 loss-offunction mutations may therefore contribute to disease pathology.

\section{Results and discussion}

Many previous studies focused on proliferating cell types that were mitotically arrested to distinguish between active and passive DNA demethylation mechanisms. Using methyl-CpG-immunoprecipitation (MCIp) and a global microarray-based approach to detect differences in DNA methylation $[21,22]$, we recently identified a number of actively demethylated regions in a natural setting of postmitotic cells: the differentiation of human peripheral blood monocytes into monocyte-derived macrophages or dendritic cells (Figure 1). DNA demethylation events were highly reproducible and paralleled or followed the appearance of 'activating' histone modifications, suggesting that a proposed DNA demethylation machinery is recruited as part of other chromatin-modifying processes associated with gene activation or transcriptional priming [23]. However, the exact mechanisms leading to DNA demethylation in human monocytes remain unclear.

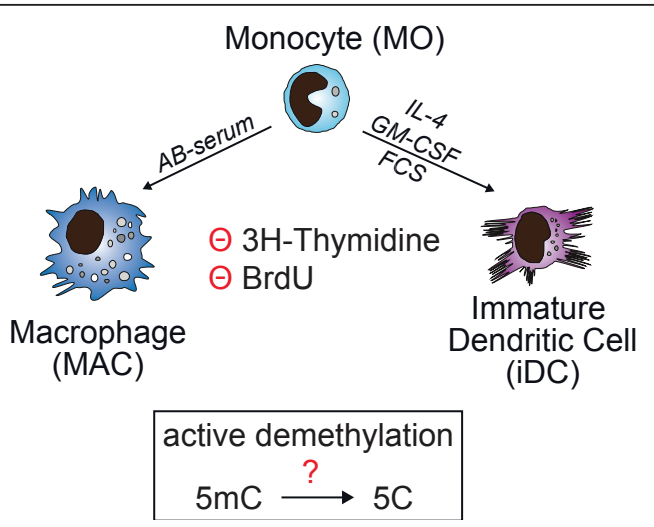

Figure 1 Monocyte differentiation in vitro. Schematic presentation of the postmitotic differentiation model of in vitro monocyte differentiation. Monocytes do not proliferate (as demonstrated by the lack of nucleotide incorporation) and DNA demethylation therefore requires an active process.

Recent studies have implicated the family of Ten-Eleven-Translocation proteins (TET1-3) in active demethylation processes via the generation of $5 \mathrm{hmC}$. To test whether TET proteins might be involved, we studied the appearance of $5 \mathrm{hmC}$ at previously defined sites of active DNA demethylation [23] in time-courses of differentiating human monocytes and compared the appearance of $5 \mathrm{hmC}$ (measured using hMeDIP) with traditional measurements of bisulfite treated DNA (which globally converts cytosines to uracil except $5 \mathrm{mC}$ and $5 \mathrm{hmC}$ ) using mass spectrometry as well as $5 \mathrm{mC}$ levels measured by MeDIP. Figure 2 summarizes the results for six different genomic regions. These loci (schematically illustrated in Figure 2A) included four regions showing DNA demethylation with either fast (CCL13, USP20) or slow kinetics as well as two control regions characterized by constitutive DNA methylation (HOXB1) or demethylation (MMP7) during the time courses. As shown in Figure $2 \mathrm{C}$, the local erasure of DNA methylation $(5 \mathrm{mC}$ and $5 \mathrm{hmC}$ as detected by mass spectrometry) was always found to correlate with the synchronous appearance of $5 \mathrm{hmC}$ (as measured by hMeDIP). At the CCL13 promoter both $5 \mathrm{mC}$ and $5 \mathrm{hmC}$ disappeared at later stages of DC differentiation, suggesting that the erasure of methylation marks might proceed to completeness (as observed at CpG dinucleotide 1) in this case. Since measurements of bisulfite treated DNA do not distinguish between $5 \mathrm{mC}$ and $5 \mathrm{hmC}$, we also followed local DNA methylation levels using MeDIP (Figure S1 in Additional File 5). While the $5 \mathrm{mC}$ antibody appeared less sensitive compared to the $5 \mathrm{hmC}$ antibody, we also observed demethylation of the four loci using this method. The local conversion of $5 \mathrm{mC}$ to $5 \mathrm{hmC}$ was further confirmed by an independent approach utilizing $5 \mathrm{hmC}$-specific 
A


|IIIII CpG dinucleotides

Epityper amplicons

ChIP-qPCR primers

\section{B}
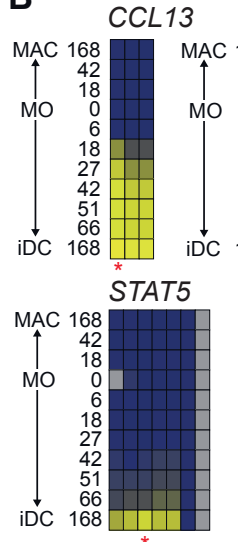

MMP7

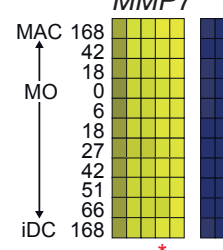

DNASE3L1

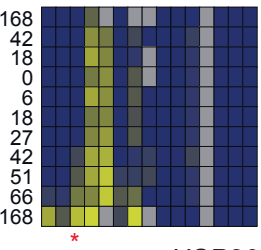

USP20

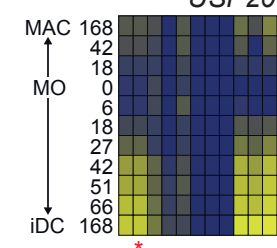

HOXB1
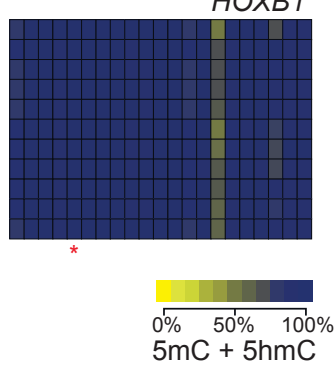

C

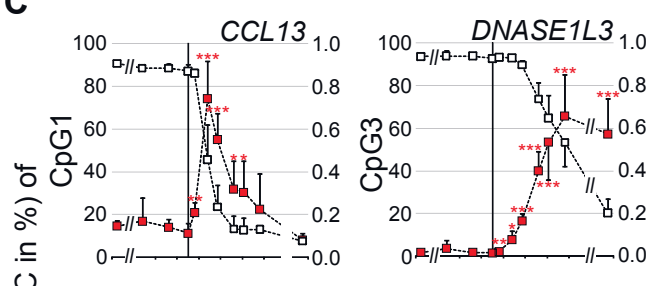

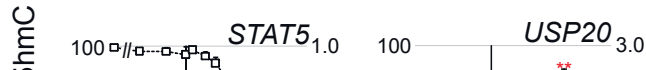
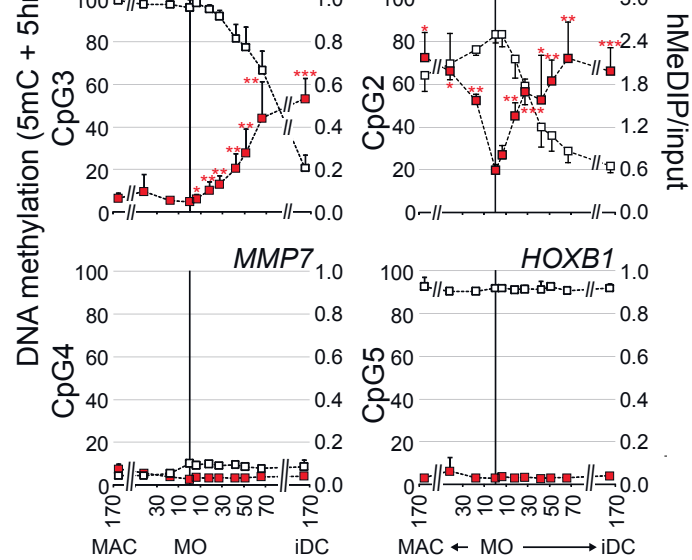

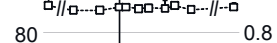

$\begin{array}{ll}0.6 & 0.6\end{array}$

$0.4 \mathrm{O}_{20} 40-0.4$

$20-0.2$

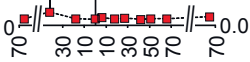

$\mathrm{MAC} \leftarrow \mathrm{MO} \longrightarrow \stackrel{\check{\mathrm{DCC}}}{\check{2}}$

Culture time (in h) $\quad \square 5 \mathrm{mC}+5 \mathrm{hmC}$

Figure $25 \mathrm{hmC}$ deposition precedes active DNA demethylation in human monocytes. (A) Positions of regions (purple) measured by MALDI-TOF analysis of bisulfite converted DNA (MassARRAY, in B) and of primers (red) used for hMeDIP qPCR (in C) are shown relative to positions of CpG dinucleotides (green) and neighboring genes (blue). Tracks were generated using the UCSC Genome Browser. (B) MassARRAY analysis of bisulfite-converted DNA at four loci that show active DNA demethylation during monocyte to DC differentiation, as well as for two control regions (values are mean of $n \geq 4$ ). Data are presented as heatmaps. The methylation content (including both $5 \mathrm{mC}$ and $5 \mathrm{hmC}$ ) is indicated by coloring (yellow: no methylation, dark blue: 100\% methylation) with each box representing a single CpG dinucleotide and each row representing the succession of CpGs measured. Grey boxes indicate CpGs that were not detected by MALDI-TOF MS. Red asterisks mark the CpGs that are shown in (C). Methylation ratios of single CpG units for individual donors are also provided in Table S2 in Additional File 2. (C) Dynamics of DNA methylation $(5 \mathrm{mC}+5 \mathrm{hmC})$ and hydroxymethylation $(5 \mathrm{hmC})$ during monocytic differentiation. DNA methylation levels of single CpGs as measured by MassARRAY (open squares) are compared with $5 \mathrm{hmC}$ enrichment (measured by hMeDIP, red squares) at the same loci shown in (B) ( $n \geq 4$, values are mean + or - SD). Exact genomic positions of analyzed CpG residues are given in Table S3 in Additional File 3.

glycosyltransferase for $5 \mathrm{hmC}$ detection by glycosylationsensitive restriction (Figure S2 in Additional File 5). These results clearly established that $5 \mathrm{hmC}$ appears at actively demethylated sites during monocyte differentiation.

To study a causal relationship between TET2 enzymes and DNA demethylation, we analyzed mRNA expression of TET genes during monocyte differentiation and found that monocytes and monocyte-derived cells primarily expressed TET2 (Figure 3). Expression of TET1 was undetectable and expression of TET3 was much weaker and less reproducible (Figure 3). In contrast to TET2 (see below) we were also unable to detect TET1 or TET3 by western blotting using commercial antibodies. These data established TET2 as the candidate enzyme for the local oxidation of $5 \mathrm{mC}$ in monocytes.

To test whether ablation of TET2 would affect the process of active DNA demethylation, we established a transient siRNA transfection protocol for freshly isolated human blood monocytes using control- or TET2-siRNA



Figure 3 TET2 is expressed in human monocytes. The expression profile of TET2 during monocyte differentiation into dendritic cells is shown. Quantitative RT-PCR results are shown relative to HPRT1 expression and represent mean values \pm SD $(n=6)$. TET3 levels were considerably lower and no mRNA expression was detected for TET1 in monocytes or monocyte-derived cells. 
before culturing them under iDC culture conditions. Monocytes are generally difficult to transfect - as sensitive sentinels of the innate immune system, they respond to foreign nucleic acids including plasmid DNA and siRNAs, which affects differentiation and survival. We thus only studied 'early' time points ( $27 \mathrm{~h}$ and $42 \mathrm{~h}$ ) after transfection where survival was largely unaffected by siRNA transfection (Figure S3A in Additional File 5). As shown by the reduced expression of the DC markers CD1a (FACS staining in Figure S3A and qRT-PCR in Figure S3B in Additional File 5) and CCL13 (qRT-PCR in Figure S3B in Additional File 5) the transfection did have an effect on the differentiation process. Concomitant, transient transfections also delayed DNA demethylation (see below), but since the process was clearly detected, the siRNA approach still allows addressing the demethylation mechanism. In addition to analyzing the effects of TET2 knockdown, we also established the siRNA-mediated knockdown of the two DNA glycosylases MBD4 and TDG that have previously been implicated in the removal of deaminated $5 \mathrm{mC}[7,24,25]$ or $5 \mathrm{hmC}$ via 5 -Carboxylcytosine $(5 \mathrm{caC})[26,27]$ in other cellular systems. As shown in Figure 4A-C the average knockdown at $27 \mathrm{~h}$ or $42 \mathrm{~h}$ ranged between $25 \%$ and $60 \%$ and $5 \%$ and $40 \%$ of control siRNA transfected cells on RNA and on protein level, respectively.

To study the effect of siRNA knockdowns, DNA methylation levels were analyzed at $27 \mathrm{~h}$ or $42 \mathrm{~h}$ using mass spectrometry of bisulfite treated DNA. Results are shown as heatmaps for the entire regions (Figure 4D) and bar charts for selected individual CpGs (Figure 4E). Interestingly, the methylation pattern derived from bisulfite treated DNA after knockdown of $M B D 4$ or TDG was undistinguishable from control siRNA treatment (Figure 4D and 4E). This

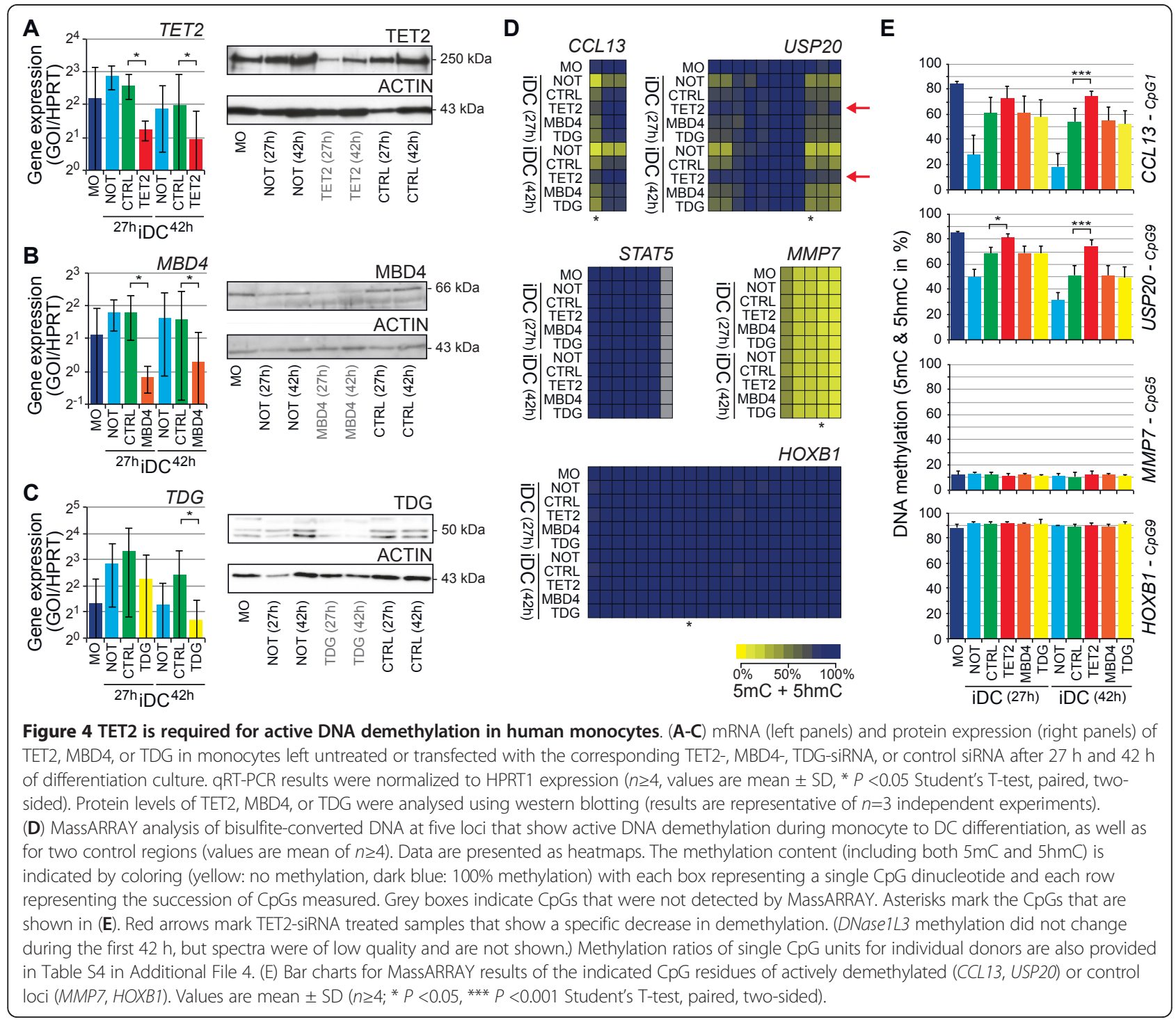


indicates that neither of these two enzymes actively converts $5 \mathrm{hmC}$, which is in line with previous observations [27]. Tet proteins were recently shown to metabolize $5 \mathrm{hmC}$ to 5 -formylcytosine (5fC) and $5 \mathrm{caC}$ [28], which are both converted into uracil during bisulfite treatment $[26,29]$. Because we cannot distinguish $5 \mathrm{fC} / 5 \mathrm{caC}$ from unmethylated cytosine residues after bisulfite treatment, we are currently not able to address whether $M B D 4$ or $T D G$ are active to 'complete' the demethylation process in primary monocytes that is initiated by TET2 mediated processing of $5 \mathrm{mC}$ into $5 \mathrm{hmC}$ and further into $5 \mathrm{fC} / 5 \mathrm{caC}$. Since human blood monocytes are (in contrast to monocyte-derived macrophages or dendritic cells) severely impaired in base and DNA double-strand break repair [30], the exchange of the two $5 \mathrm{mC}$ derivatives may be delayed. To test whether $5 \mathrm{fC} / 5 \mathrm{caC}$ accumulate as the end product of the demethylation process at the CCL13 promoter, we analyzed the restriction efficiency of $M s p I$ (which is inhibited by the presence of $5 \mathrm{caC}$ or $5 \mathrm{fC} \mathrm{[28])} \mathrm{at} \mathrm{the} \mathrm{site} \mathrm{cover-}$ ing one of the demethylated CpGs. While MspI can also be inhibited by methylation of the outer C (5mCCGG) and thus may not allow the quantification of $5 \mathrm{caC}$ or $5 \mathrm{fC}$, the fact that DNA from iDC (as well as from all knockdown experiments) could be efficiently cut with this restriction enzyme (Figure S4 in Additional File 5) suggests that the demethylation process is completed $(5 \mathrm{mC} \rightarrow 5 \mathrm{C})$ in iDC. $M B D 4$ or TDG knockdown did not lead to a decrease in restriction efficiency, indicating that $5 \mathrm{caC}$ or $5 \mathrm{fC}$ do not accumulate at these sites in transfected monocytes. It is thus still unclear whether TDG, MBD4, or another enzyme initiates the last steps of the active demethylation process. Notably, a recent mass spectrometry study systematically identified readers in embryonic stem cells, neuronal progenitor cells, and brain for all known 5C derivates [31]. This study identified a number of additional DNA glycosylases (Neil1, Neil3), as well as helicases (Hells, Harp, Recql, and its homolog Bloom) binding specifically to hmC suggesting that this derivate may already attract DNA-repair enzymes and perhaps initiate DNA demethylation in differentiating monocytes.

The TET2-siRNA treatment, however, resulted in significantly different methylation patterns: the local loss of DNA methylation at the two loci showing rapid $5 \mathrm{mC}$ erasure (CCL13 and USP20) was significantly delayed in cells with reduced TET2 expression (Figure 4D and 4E), while control regions were unaffected and the late demethylation targets did not show any signs of methylation loss at these early time points. We also analyzed local $5 \mathrm{hmC}$ levels using hMeDIP (Figure S5A in Additional File 5), as well as glycosylation-sensitive restriction (Figure S5B in Additional File 5) and detected a significant reduction of $5 \mathrm{hmC}$ at demethylated regions only in TET2-siRNA-treated monocytes. These results clearly establish that differentiating monocytes require TET2 to initiate the active demethylation process.
As shown previously, DNA demethylation in primary monocytes is characterized by the parallel appearance of activating histone marks, such as mono- and dimethylation of H3K4 or acetylation of histones $\mathrm{H} 3$ and H4 [23], which are typical features of enhancers. This is also in line with the recent observation of dynamic deposition of $5 \mathrm{hmC}$ at differentiation-associated enhancers in other cellular systems [32]. The histone modifications likely follow the recruitment of DNA-binding factors that direct histone methyl- and/or acetyl-transferases to these sites [23]. The local appearance of $5 \mathrm{hmC}$ suggests that the modified histones or the same factors responsible for the modification of histones may also recruit the 5-methylcytosine dioxygenase TET2 to initiate DNA demethylation of newly activated and/or remodeled sites.

\section{Conclusions}

Our data unequivocally show that the TET2-mediated conversion of $5 \mathrm{mC}$ to $5 \mathrm{hmC}$ is an essential intermediate in targeted, locus-specific active demethylation processes that are observed during the differentiation of non-dividing human monocytes. This function of TET2 may also be essential for the differentiation of earlier myeloid progenitor stages, as a significant proportion of myeloid dysplasia are characterized by loss-of-function mutations of TET2.

\section{Materials and methods \\ Cells}

Collection of blood cells from healthy donors was performed in compliance with the Helsinki Declaration. All donors signed an informed consent. The leukapheresis procedure, the subsequent purification of peripheral blood monocytes by density gradient centrifugation over Ficoll/Hypaque as well as the counter current centrifugal elutriation were approved by the local ethical committee (reference number 92-1782 and $09 / 066 \mathrm{c}$ ). The generation of monocyte-derived dendritic cells and macrophages has been described previously [23].

\section{DNA isolation}

Genomic DNA was prepared using the DNeasy Blood and Tissue Kit from Qiagen (Hilden, Germany).

\section{Mass spectrometry analysis of bisulfite-converted DNA}

Sodium bisulfite conversion and quantitative analysis of DNA methylation using MALDI-TOF mass spectrometry (MassARRAY Compact MALDI-TOF, Sequenom, San Diego, CA, USA) was performed as described [23,33]. Primers for amplicon generation were described [23] or are listed in Table S1 in Additional File 1. 


\section{hMeDIP \& MeDIP}

Enrichment of 5- methylcytosine (5mC) or 5-hydroxymethylcytosine $(5 \mathrm{hmC})$ was analyzed by immunoprecipitation using 5-methylcytidine and 5-hydroxy-methylcytidine antibodies (Diagenode and Active Motif, respectively) essentially as described for $5 \mathrm{mC}$ in Mohn et al. [34]. Enriched DNA was purified with the PCR purification kit from Qiagen and quantified on a Realplex Mastercycler EP (Eppendorf, Hamburg, Germany) using the Quantifast SYBR Green PCR Kit (Qiagen) as indicated by the manufacturer. Primer sequences were previously described or are listed in Table S1 in Additional File 1.

\section{Glycosylation of $5 \mathrm{hmC}$}

Site-specific detection of $5 \mathrm{hmC}$ by glycosylation was done using the Quest 5-hmC detection kit (Zymo Research) following the manufacturer's instructions with modifications. After the glycosylation step (prolonged to $3 \mathrm{~h}$ ), samples were cleaned using the DNA clean and concentrator kit (Zymo) and subsequently digested with $30 \mathrm{U}$ MspI (NEB), or $30 \mathrm{U}$ HpaII (NEB) at $37^{\circ} \mathrm{C}$ overnight. The fraction of glycosylated and therefore protected $M s p \mathrm{I}$ sites as well as the fraction of $5 \mathrm{mC}$ - and $5 \mathrm{hmC}$-sensitive sites (determined using HpaII restriction) at specific gene loci were quantified by qPCR using primers described in [23] or primers listed in Table S1 in Additional File 1.

\section{Quantitative RT-PCR}

Total cellular RNA was isolated using the RNeasy Mini Kit (Qiagen) and reverse transcribed using Superscript II MMLV-RT (Promega, Mannheim, Germany). Real-time PCR was performed on a Realplex Mastercycler EP (Eppendorf, Hamburg, Germany) as described above. Primer sequences are listed in Table S1 in Additional File 1.

\section{Transfection of primary human monocytes}

Peripheral blood monocytes were transfected using the Human Monocyte Nucleofector Kit from Lonza (Cologne, Germany). In brief, $6 \times 10^{6}$ cells were resuspended in 100 $\mu \mathrm{L}$ Nucleofector solution (Lonza) with 600 nM TET2-, MBD4-, TDG-, or control-siRNA (all from Thermo Scientific Dharmacon) and electroporated using the Nucleofector I device. Cells were cultured as described without the addition of antibiotics. Expression of targeted genes as well as DNA methylation was measured after $27 \mathrm{~h}$ or $42 \mathrm{~h}$ in culture.

\section{Western blotting}

To follow knockdown efficiency on protein level, cells were harvested $27 \mathrm{~h}$ and $42 \mathrm{~h}$ after transfection, washed with PBS and lysed in 2x SDS-Lysis Buffer $(20 \%$ Glycerin, 125mM Tris pH 6.8, 4\% SDS, 10\% 2-Mercaptoethanol, $0.02 \%$ Bromophenolblue). Lysates were boiled $\left(95^{\circ} \mathrm{C}, 10 \mathrm{~min}\right)$ and $1.5 \times 10^{5}$ to $5 \times 10^{5}$ cells per lane separated on $8 \%$ or $10 \%$ polyacrylamide gels (Biometra Minigel Gelelectrophoresis device). Proteins were transferred to nitrocellulose membranes (Live Technologies, $0.45 \mu \mathrm{M}$ pore size) using the Biometra Fastblot semi-dry blotter or the Biorad Mini Transblot Cell wet system according to the protein size. After $1 \mathrm{~h}$ of blocking in TBS-T with $5 \%$ dry milk at room temperature the membranes were incubated with either Anti-TET2 (1:2,000, a gift from O. Bernard), Anti-TDG (1:10,000, a gift from Primo Schär), Anti-MBD4 (1:2,000, from Diagenode) or Anti-actin (Sigma Aldrich) overnight at $4^{\circ} \mathrm{C}$. Second antibody (Dako, Glostrup, Denmark) incubation was carried out at room temperature for $1 \mathrm{~h}$. Flourescence signals were detected after exposure to ECL hyperfilm or using a fluorescence scanner (BioRad, Chemi Doc XRS+).

\section{Quantification of $M s p l$ restriction efficiency}

DNA from monocyte-derived dendritic cells (iDC, 100ng) was digested with $M s p$ I plus $H h a \mathrm{I}$ or with $H$ haI alone (20 $\mathrm{U}$ each, New England BioLabs) overnight (approximately $16 \mathrm{~h}$ ) at $37^{\circ} \mathrm{C}$. The efficiency of $M s p \mathrm{I}$ cutting was measured by comparing the qPCR amplification of DNA fragments across the $M s p$ I site in MspI-digested and -undigested DNA samples.

\section{Additional material}

Additional file 1: Table S1. Word DocumentTitle of this dataset: Table S1, Oligonucleotide sequences used for PCRDescription of this dataset: Table S1 lists sequences of oligonucleotides for various PCR-based analyses.

Additional File 2: Table S2. Excel FileTitle of this dataset: Table S2, EpiTYPER resultsDescription of this dataset: Table S2 lists MassARRAY EpiTYPER results. EpiTYPER methylation ratios of individual $\mathrm{CpG}$ units in 12 amplicons covering six distinct genomic locations are given for all knockdown samples of different donors.

Additional file 3: Table S3. Excel FileTitle of this dataset: Table S2, EpiTYPER resultsDescription of this dataset: Table S2 lists MassARRAY EpiTYPER results. EpiTYPER methylation ratios of individual $\mathrm{CpG}$ units in 12 amplicons covering six distinct genomic locations are given for all time course samples of different donors.

Additional file 4: Table S4. Word DocumentTitle of this dataset: Table S2, Genomic position of analyzed CpG residuesDescription of this dataset: Table S2 lists genomic positions of $\mathrm{CpG}$ residues that were analyzed by MassARRAY or QUEST-qPCR.

Additional file 5: Supplementary Figures. PDFTitle of this dataset: Supplementary FiguresDescription of this dataset: Contains supplementary figures $\mathrm{S} 1-5$.

\section{Abbreviations}

5caC: 5-carboxylcytosine; 5fC: 5-formylcytosine; $5 \mathrm{hmC:}$ 5-

hydroxymethylcytosine; 5mC: 5-methylcytosine; BrdU: 5-Bromo-2'-deoxyuridine; iDC: immature dendritic cell; MO: monocyte; MAC: macrophage

\section{Authors' contributions}

MK participated in study design, performed experiments, analyzed data, and aided in the manuscript preparation. SS performed experiments, analyzed 
data, and aided in the manuscript preparation. CG performed and analyzed experiments. RA participated in study design. MR conceived and coordinated the study, analyzed data, and drafted the manuscript. All authors read and approved the final manuscript.

\section{Competing interests}

The authors declare that they have no competing interests.

\section{Acknowledgements}

The authors thank Ireen Ritter, Lucia Schwarzfischer-Pfeilschifter, and Dagmar Glatz for excellent technical assistance. They are also grateful to Olivier Bernard for sharing the TET2 antiserum and to Primo Schär for providing his TDG antibody. This work was funded by a grant from the Deutsche Forschungsgemeinschaft to MR (RE1310/7).

\section{Author details}

'Department of Internal Medicine III, University Hospital Regensburg, D93042 Regensburg, Germany. ${ }^{2}$ Regensburg Centre for Interventional Immunology (RCI), D-93042 Regensburg, Germany. ${ }^{3}$ German Cancer Research Center (DKFZ), D-69120 Heidelberg, Germany.

Received: 10 October 2012 Revised: 15 May 2013

Accepted: 26 May 2013 Published: 26 May 2013

\section{References}

1. Bird A: DNA methylation patterns and epigenetic memory. Genes Dev 2002, 16:6-21.

2. Jaenisch $\mathrm{R}$, Bird A: Epigenetic regulation of gene expression: how the genome integrates intrinsic and environmental signals. Nat Genet 2003, Suppl:245-254.

3. Ooi SK, Bestor TH: The colorful history of active DNA demethylation. Cell 2008, 133:1145-1148

4. Tahiliani M, Koh KP, Shen Y, Pastor WA, Bandukwala H, Brudno Y, Agarwal S, lyer LM, Liu DR, Aravind L, Rao A: Conversion of 5-methylcytosine to 5hydroxymethylcytosine in mammalian DNA by MLL partner TET1. Science 2009, 324:930-935.

5. Ito S, D'Alessio AC, Taranova OV, Hong K, Sowers LC, Zhang Y: Role of Tet proteins in $5 \mathrm{mC}$ to $5 \mathrm{hmC}$ conversion, ES-cell self-renewal and inner cell mass specification. Nature 2010, 466:1129-1133.

6. Koh KP, Yabuuchi A, Rao S, Huang Y, Cunniff K, Nardone J, Laiho A, Tahiliani M, Sommer CA, Mostoslavsky G, Lahesmaa R, Orkin SH, Rodig SJ, Daley GQ, Rao A: Tet1 and Tet2 regulate 5-hydroxymethylcytosine production and cell lineage specification in mouse embryonic stem cells. Cell Stem Cell 2011, 8:200-213.

7. Zhu JK: Active DNA demethylation mediated by DNA glycosylases. Annu Rev Genet 2009, 43:143-166.

8. Iqbal K, Jin SG, Pfeifer GP, Szabo PE: Reprogramming of the paternal genome upon fertilization involves genome-wide oxidation of 5methylcytosine. Proc Natl Acad Sci USA 2011, 108:3642-3647.

9. Yamaguchi S, Hong K, Liu R, Inoue A, Shen L, Zhang K, Zhang Y: Dynamics of 5-methylcytosine and 5-hydroxymethylcytosine during germ cell reprogramming. Cell Res 2013, 23:329-339.

10. Kagiwada S, Kurimoto K, Hirota T, Yamaji M, Saitou M: Replication-coupled passive DNA demethylation for the erasure of genome imprints in mice. EMBO J 2013, 32:340-353.

11. Gu TP, Guo F, Yang H, Wu HP, Xu GF, Liu W, Xie ZG, Shi L, He X, Jin SG, labal K, Shi YG, Deng Z, Szabo PE, Pfeifer GP, Li J, Xu GL: The role of Tet3 DNA dioxygenase in epigenetic reprogramming by oocytes. Nature 2011, 477:606-610.

12. Inoue A, Zhang Y: Replication-dependent loss of 5hydroxymethylcytosine in mouse preimplantation embryos. Science 2011, 334:194.

13. Wossidlo M, Nakamura T, Lepikhov K, Marques CJ, Zakhartchenko V, Boiani M, Arand J, Nakano T, Reik W, Walter J: 5-Hydroxymethylcytosine in the mammalian zygote is linked with epigenetic reprogramming. Nat Commun 2011, 2:241.

14. Delhommeau F, Dupont S, Della Valle V, James C, Trannoy S, Masse A, Kosmider O, Le Couedic JP, Robert F, Alberdi A, Lecluse Y, Plo I, Dreyfus FJ, Marzac C, Casadevall N, Lacombe C, Romana SP, Dessen P, Soulier J, Viguie F, Fontenay M, Vainchenker W, Bernard OA: Mutation in TET2 in myeloid cancers. N Engl J Med 2009, 360:2289-2301.
15. Langemeijer SM, Kuiper RP, Berends M, Knops R, Aslanyan MG, Massop M, Stevens-Linders $E$, van Hoogen P, van Kessel AG, Raymakers RA, Kamping EJ, Verhoef GE, Verburgh E, Hagemeijer A, Vandenberghe $P$, de Witte T, van der Reijden BA, Jansen $\mathrm{HH}$ : Acquired mutations in TET2 are common in myelodysplastic syndromes. Nat Genet 2009, 41:838-842.

16. Mullighan CG: TET2 mutations in myelodysplasia and myeloid malignancies. Nat Genet 2009, 41:766-767.

17. Ko M, Bandukwala HS, An J, Lamperti ED, Thompson EC, Hastie R, Tsangaratou A, Rajewsky K, Koralov SB, Rao A: Ten-Eleven-Translocation 2 (TET2) negatively regulates homeostasis and differentiation of hematopoietic stem cells in mice. Proc Natl Acad Sci USA 2011, 108:14566-14571.

18. Ko M, Huang Y, Jankowska AM, Pape UJ, Tahiliani M, Bandukwala HS, An J, Lamperti ED, Koh KP, Ganetzky R, Liu XS, Aravind L, Agarwal S, Maciejewski JP, Rao A: Impaired hydroxylation of 5-methylcytosine in myeloid cancers with mutant TET2. Nature 2010, 468:839-843.

19. Moran-Crusio K, Reavie L, Shih A, Abdel-Wahab O, Ndiaye-Lobry D, Lobry C, Figueroa ME, Vasanthakumar A, Patel J, Zhao X, Perna F, Pandey S, Madzo J, Song C, Dai Q, He C, Ibrahim S, Beran M, Zavadil J, Nimer SD, Melnick A, Godley LA, Aifantis I, Levine RL: Tet2 loss leads to increased hematopoietic stem cell self-renewal and myeloid transformation. Cancer Cell 2011, 20:11-24.

20. Pronier E, Almire C, Mokrani H, Vasanthakumar A, Simon A, da Costa Reis Monte Mor B, Masse A, Le Couedic JP, Pendino F, Carbonne B, Larghero J, Ravanat JL, Casadevall N, Bernard OA, Droin N, Solary E, Godley LA, Vainchenker W, Plo I, Delhommeau F: Inhibition of TET2-mediated conversion of 5-methylcytosine to 5-hydroxymethylcytosine disturbs erythroid and granulomonocytic differentiation of human hematopoietic progenitors. Blood 2011, 118:2551-2555.

21. Gebhard C, Schwarzfischer L, Pham TH, Schilling E, Klug M, Andreesen R, Rehli M: Genome-wide profiling of CpG methylation identifies novel targets of aberrant hypermethylation in myeloid leukemia. Cancer Res 2006, 66:6118-6128.

22. Schmidl C, Klug M, Boeld TJ, Andreesen R, Hoffmann P, Edinger M, Rehli M: Lineage-specific DNA methylation in T cells correlates with histone methylation and enhancer activity. Genome Res 2009, 19:1165-1174.

23. Klug M, Heinz S, Gebhard C, Schwarzfischer L, Krause SW, Andreesen R, Rehli M: Active DNA demethylation in human postmitotic cells correlates with activating histone modifications, but not transcription levels. Genome Biol 2010, 11:R63.

24. Kim MS, Kondo T, Takada I, Youn MY, Yamamoto Y, Takahashi S, Matsumoto T, Fujiyama S, Shirode Y, Yamaoka I, Kitagawa H, Takeyama K, Shibuya $\mathrm{H}$, Ohtake F, Kato S: DNA demethylation in hormone-induced transcriptional derepression. Nature 2009, 461:1007-1012.

25. Zhu B, Zheng Y, Angliker H, Schwarz S, Thiry S, Siegmann M, Jost JP: 5Methylcytosine DNA glycosylase activity is also present in the human MBD4 (G/T mismatch glycosylase) and in a related avian sequence. Nucleic Acids Res 2000, 28:4157-4165.

26. He YF, Li BZ, Li Z, Liu P, Wang Y, Tang Q, Ding J, Jia Y, Chen Z, Li L, Sun Y, Li X, Dai Q, Song CX, Zhang K, He C, Xu GL: Tet-mediated formation of 5carboxylcytosine and its excision by TDG in mammalian DNA. Science 2011, 333:1303-1307.

27. Zhang L, Lu X, Lu J, Liang H, Dai Q, Xu GL, Luo C, Jiang H, He C: Thymine DNA glycosylase specifically recognizes 5-carboxylcytosine-modified DNA. Nat Chem Biol 2012, 8:328-330.

28. Ito S, Shen L, Dai Q, Wu SC, Collins LB, Swenberg JA, He C, Zhang Y: Tet proteins can convert 5-methylcytosine to 5-formylcytosine and 5-carboxylcytosine. Science 2011, 333:1300-1303.

29. Booth MJ, Branco MR, Ficz G, Oxley D, Krueger F, Reik W, Balasubramanian S: Quantitative sequencing of 5-methylcytosine and 5-0hydroxymethylcytosine at single-base resolution. Science 2012, 336:934-937.

30. Bauer M, Goldstein M, Christmann M, Becker H, Heylmann D, Kaina B: Human monocytes are severely impaired in base and DNA doublestrand break repair that renders them vulnerable to oxidative stress. Proc Natl Acad Sci USA 2011, 108:21105-21110.

31. Spruijt CG, Gnerlich F, Smits AH, Pfaffeneder T, Jansen PW, Bauer C, Munzel M, Wagner M, Muller M, Khan F, Eberl HC, Mensinga A, Brinkman AB, Lephikov K, Muller U, Walter J, Boelens R, van Ingen $H$, Leonhardt H, Carell T, Vermeulen M: Dynamic readers for 5-(hydroxy) methylcytosine and its oxidized derivatives. Cell 2013, 152:1146-1159. 
32. Serandour AA, Avner S, Oger F, Bizot M, Percevault F, Lucchetti-Miganeh C, Palierne G, Gheeraert C, Barloy-Hubler F, Peron CL, Madigou T, Durand E, Froguel P, Staels B, Lefebvre P, Metivier R, Eeckhoute J, Salbert G: Dynamic hydroxymethylation of deoxyribonucleic acid marks differentiationassociated enhancers. Nucleic Acids Res 2012, 40:8255-8265.

33. Gebhard C, Benner C, Ehrich M, Schwarzfischer L, Schilling E, Klug M, Dietmaier W, Thiede C, Holler E, Andreesen R, Rehli M: General transcription factor binding at $\mathrm{CpG}$ islands in normal cells correlates with resistance to de novo DNA methylation in cancer cells. Cancer Res 2010, 70:1398-1407.

34. Mohn F, Weber M, Schubeler D, Roloff TC: Methylated DNA immunoprecipitation (MeDIP). Methods Mol Biol 2009, 507:55-64.

doi:10.1186/gb-2013-14-5-r46

Cite this article as: Klug et al: 5-Hydroxymethylcytosine is an essential intermediate of active DNA demethylation processes in primary human monocytes. Genome Biology 2013 14:R46.

\section{Submit your next manuscript to BioMed Central} and take full advantage of:

- Convenient online submission

- Thorough peer review

- No space constraints or color figure charges

- Immediate publication on acceptance

- Inclusion in PubMed, CAS, Scopus and Google Scholar

- Research which is freely available for redistribution

Submit your manuscript at www.biomedcentral.com/submit 